\title{
Assessing of Antidiabetic and Ameliorative Effect of Lupin Seed Aqueous Extract on Hyperglycemia, Hyperlipidemia and Effect on pdx1, Nkx6.1, Insulin-1, GLUT-2 and Glucokinase Genes Expression in Streptozotocin-induced Diabetic Rats
}

\author{
Basma H. Marghani ${ }^{1, *}$, Ahmed I. Ateya ${ }^{2}$, Rasha M. Saleh ${ }^{1}$, Rasha A. Eltaysh ${ }^{3}$ \\ ${ }^{1}$ Department of Physiology, Faculty of Veterinary Medicine, Mansoura University, 35516, Egypt \\ ${ }^{2}$ Department of Animal Husbandry and Animal Wealth Development, Faculty of Veterinary Medicine, \\ Mansoura University, 35516, Egypt \\ ${ }^{3}$ Department of Pharmacology, Faculty of Veterinary Medicine, Mansoura University, 35516, Egypt \\ *Corresponding author: basmahamed@mans.edu.eg, basmahamed61@yahoo.com
}

Received January 14, 2019; Revised February 22, 2019; Accepted April 19, 2019

\begin{abstract}
Diabetes mellitus (DM) belong to the major health problems causing mortality and morbidity in the world. Our study aimed to investigate effects of Lupinus Albus (LA) seed extract on streptozotocin (STZ)-induced diabetic rats. Thirty mature Sprague Dawley male rats were used in this study. Three experimental groups were used as follows: GI- Control rats (Normal), GII- Diabetic rats and GIII- Diabetic rats treated with LA aqueous extract (7mg/100g B.wt) by oral gavage. Insulin, Fasting blood glucose (FBG), glycosylated hemoglobin (HbAlc) and serum lipid profile assays of all rats were carried out. Gene expressions of Pancreatic and duodenal homeobox 1 (Pdx-1), homeobox protein (Nkx6.1), insulin-1, liver glucose transporter-2 (GLUT-2) and glucokinase were performed by real-time PCR. Results obtained for diabetic rats orally gavage with LA extract revealed an improvement in insulin with reduction in $\mathrm{FBG}, \mathrm{HbAlc} \%$ and significant improvement in serum lipid profile. Additionally, LA aqueous extract induced a mild increase in expression of biomarkers genes for pancreatic $\beta$ eta cells ( $\beta$-cells) function, insulin secretion, liver GLUT-2 and glucokinase when compared to STZ-diabetic rats. This research highlights $L A$ seed extract as a nutraceutical for improving insulin secretion in diabetic rats.
\end{abstract}

Keywords: lupin, diabetes mellitus, hyperglycemia, hyperlipidemia, insulin secretion

Cite This Article: Basma H. Marghani, Ahmed I. Ateya, Rasha M. Saleh and Rasha A. Eltaysh "Assessing of Antidiabetic and Ameliorative Effect of Lupin Seed Aqueous Extract on Hyperglycemia, Hyperlipidemia and Effect on pdx1, Nkx6.1, Insulin-1, GLUT-2 and Glucokinase Genes Expression in Streptozotocin-induced Diabetic Rats." Journal of Food and Nutrition Research, vol. 7, no. 5 (2019): 333-341. doi: 10.12691/jfnr-7-5-1.

\section{Introduction}

DM one of the metabolic diseases, consequential to a defect in insulin secretion from $\beta$-cells or defect in sensitivity of target tissues to insulin and resulted in hyperglycemia associated with alteration in metabolism of carbohydrate, fat and protein [1]. DM was considered serious health problems resulted in mortality and morbidity in the world [2]. Type-1 Diabetes mellitus (T1DM) happens when beta cells ( $\beta$-cells) of pancreas recognized by the auto-reactive $T$ cells [3], destroys these cells and subsequent loss of insulin secretion.

The physiological effects of insulin are started with binding of insulin to its membrane receptor that stimulates activity of the intrinsic protein tyrosine kinase and subsequent phosphorylation of a cascade of interacting proteins, including those of the insulin receptor substrate (IRS) [4]. Pdx-1 sustains the adult beta cells phenotypes and essential for their survival [5]. It is vital for the expression, processing and secretion of insulin as well as glucose homeostatic regulation [6]. Nkx6.1 is important for the final differentiation of $\beta$-cells as well as being essential and adequate for specifying the identity of $\beta$ cells and production of insulin [7].

STZ is synthesized by streptomycetes achromogenes and it is used as an antibiotic that produces $\beta$-cells pancreatic islets damage and is widely used to induce an experimental model of T1DM [8]. Also, it was accepted by Food and Drug Administration (FDA) in the metastatic cancer of pancreatic islets cells via impeding glucose oxidation and stimulation of insulin secretion from $\beta$-cells through DNA fragmentation followed by a continuous 
decrease in cellular nicotinamide adenine dinucleotide (NAD+) levels that induces cell death $[9,10]$. STZ induced beta cell damage as well as liver and kidney toxicity [11]. STZ internalized through GLUT-2, which is located on pancreatic beta cells, liver, kidney and small intestine acting as a transmembrane carrier protein and the main glucose transporter and sensor in rodent islets [12]. GLUT-2 gene expression levels in pancreas are defined as a marker for the degree of susceptibility to STZ in different animal models [13]. Single nucleotide polymorphisms (SNPs) in GLUT-2 gene were found to predict conversion to diabetes from impaired glucose tolerance [13].

Micro and macro vascular complications of DM can be reduced through the effective treatments of diabetes-induced hyperglycemia [14]. Nowadays, approach for treatment of diabetes induced-hyperglycemia was directed to use the most potent, effective and safe natural medicinal plants instead of the anti-diabetic drugs to avoid their side effects on diabetic patients [15,16]. Lupinus Albus (LA) is an annual plant, one type of legumes, used for human nutrition as a protein source and exemplifies as an anti-hyperglycemic plant $[17,18]$. It possesses hypoglycemic effects via augmented secretion of insulin from $\beta$-cells [19]. Aqueous extract of $L A$ seeds encourages the release of insulin from cultured $\beta$-cells [20]. Furthermore, $L A$ is rich in lupine proteins that belong to $11 \mathrm{~S}$ and $7 \mathrm{~S}$ globulins; one type of this globulin is conglutin- $\gamma$ which represented about $5 \%$ of the total globulins, show insulin-simulated effects in cultured cells and has hypoglycemic effect that was demonstrated in different experimental animals $[21,22]$.

The anti-hyperglycemic LA mechanism of action was not clearly studied; therefore, our study has been carried out to investigate the potential anti-diabetic effects of LA seed extract on hyperglycemia and hyperlipidemia in diabetic rats and to evaluate its effect on insulin action based on a molecular level, focusing on its effect on pancreatic insulin-1, Pdx-1 and Nkx6.1 and liver glucokinase and GLUT-2 gene expression.

\section{Materials and Methods}

\subsection{Chemicals and Reagents}

Streptozotocin powder (STZ 2-deoxy-2(methyl nitrosamine) carbonyl) amino) -D-glucopyranose), Commercial rodent insulin Elisa kit (Crystal chem), HbAlc commercial Kit (BioSystem, Spain), TC, TAG and HDL-C commercial kit (Spectrum diagnostic kit) were purchased from (Sigma Aldrich Chemical Co (St. Louis, MO, USA). Trizol, SensiFast $^{\mathrm{TM}}$ cDNA synthesis kit Bioline, catalogNo. Bio65053), PCR Master Mix (2x SensiFast ${ }^{\mathrm{TM}}$ SYBR, Bioline, catalog No. Bio-98002).

\subsection{Animals and Housing Conditions}

Thirty mature Sprague Dawley male rats, average weight $180 \pm 5 \mathrm{~g}$, obtained from the Helwan animal house- Egypt, kept in separate cages at physiology department- Faculty of Veterinary Medicine-Mansoura University-Egypt. All rats are sustained in standard laboratory conditions (12 h light: $12 \mathrm{~h}$ dark cycles) and provided with standard basal diet required for rats [23] and water ad-libitum for 60 days. All the animal procedures were performed in accordance with the Ethics Committee of the National Research Centre- Egypt with registration number (09/189).

\subsection{Plant Material and Preparation of Lupinus albus (LA) Aqueous Extract}

Lupine seeds, available commercially were purchased from the herbal store-Mansoura, Egypt. LA seeds were crushed finely and boiled in distilled water $(5 \mathrm{~g}$ of the seeds powder in $200 \mathrm{ml} \mathrm{D.W}$ ), the suspension was sieved to remove the deposit. The extract solution was stored in the refrigerator to avoid possible deterioration of active ingredients. $L A$ extract was administered to rats with a dose $(7 \mathrm{mg} / 100 \mathrm{~g} \mathrm{B.wt})$ orally by gavage daily for 60 days [24].

\subsection{Induction of Experimental Diabetes in Rats by STZ}

Twenty male rats were injected intraperitoneal (IP) with STZ (50 mg/kg B.wt) that was dissolved previously in cold $0.1 \mathrm{M}$ citrate buffer ( $\mathrm{PH}$ is 4.5 ) after overnight fasting [25]. Following STZ injection, 5\% glucose water was given to all animals for one day to avoid hypoglycemic mortality due to leakage of insulin from damaged $\beta$ cells [26]. After three days from STZ injection of STZ, the rats were fasted for $12 \mathrm{hr}$, anaesthetized with ether, a small drop of blood, obtained by pricking the skin with a lancet, is placed on a disposable test strip of the glucometer (One touch technology) that the meter reads and calculate the blood glucose level in units of $\mathrm{mg} / \mathrm{dl}$. Diabetic animals exhibited hyperglycemia (blood glucose higher than $250 \mathrm{mg} / \mathrm{dl}$ ) and symptoms of polyuria and polydipsia were involved in this experiment [27]. Treatment with $L A$ extract was ongoing 3 days after diabetes induction and continued for a period of 60 days.

\subsection{Experimental Protocol}

Experimental rats were categorized into three groups (Ten rats in each, divided into two cages):

GI-Control normal rats

GII-Diabetic non-treated rats

GroupIII-Diabetic rats, treated with $L A$ aqueous extract $(7 \mathrm{mg} / 100 \mathrm{~g}$ B.wt) orally by gavage daily for 60 constitutive days [24].

\subsection{Blood Sampling}

At the end of the experimental period, rats were fasted overnight, anaesthetized by diethyl ether. Blood samples were collected from retro-orbital plexus, immediately divided into two sterile dry capped tubes; one contained $\mathrm{Na}_{2}$-EDTA as an anticoagulant for HbA1c analysis. The other tube was used for serum sample separation by centrifugation of blood sample at $3000 \mathrm{~g}$ for 15 minutes. Non-hemolyzed serum samples were stored in a deep freezer for further biochemical analysis. 


\subsection{Tissue Sampling}

After the experimental period, the rat's abdomen incised then pancreas and liver were dissected out from each animal, immediately frozen in liquid nitrogen for total RNA extraction and subsequent molecular investigation of genes expression.

\subsection{Estimation of Biochemical Parameters}

\subsubsection{Quantitative Measurement of Insulin}

Insulin was assayed by competitive Enzyme-Linked Immune Sorbent Assay (ELIZA) method, using a commercial rodent insulin Elisa kit (Crystal chem) [28].

\subsubsection{Estimation of Glycosylated Hemoglobin (HbA1c)}

Glycosylated hemoglobin (HbA1c) was estimated by a commercial Kit (BioSystem, Spain) [29].

\subsubsection{Estimation of Lipid Profile}

Serum TC, TAG and HDL-C levels were measured by a commercial kit (Spectrum Diagnostic kit) $[30,31,32]$.

For the determination of LDL-C and VLDL-C, Fried Wald formulae were used as: LDL-C $=$ TC $-($ VLDL-C + HDL-C) and VLDL-C=TG/5 [32].

\subsection{Total RNA Extraction and Reverse Transcription}

Total RNA was extracted from pancreatic and liver tissues using Trizol reagent according to the manufacturer's instructions (Direct-zol ${ }^{\mathrm{TM}}$ RNA MiniPrep, catalog No. R2050). The amount of extracted RNA was quantified and qualified using NanoDrop ${ }^{\circledR}$ ND-1000 Spectrophotometer. The cDNA of each sample was synthesized following the manufacture protocol (SensiFast ${ }^{\mathrm{TM}}$ cDNA synthesis kit, Bioline, catalog No. Bio- 65053). The reaction mixture was carried out in a total volume $20 \mu \mathrm{L}$ consisted of total RNA up to $1 \mu \mathrm{g}, 4 \mu \mathrm{L} 5 \mathrm{x}$ Trans Amp buffer, $1 \mu \mathrm{L}$ reverse transcriptase and DNase free-water up to $20 \mu \mathrm{L}$. The final reaction mixture was placed in a thermal cycler and the following program was carried out; primer annealing at $25^{\circ} \mathrm{C}$ for $10 \mathrm{~min}$, reverse transcription at $42^{\circ} \mathrm{C}$ for $15 \mathrm{~min}$ followed by inactivation at $85^{\circ} \mathrm{C}$ for $5 \mathrm{~min}$. The samples were held at $4^{\circ} \mathrm{C}$.

\subsection{Quantitative Real Time PCR}

Absolute quantification of mRNA levels of pancreatic Pdx-1, Nkx6.1, insulin-1 and liver GLUT-2, glucokinase was performed by real-time PCR via SYBR Green PCR Master Mix (2x SensiFast ${ }^{\mathrm{TM}}$ SYBR, Bioline, catalog No. Bio-98002). Table 1 shows primer sequences and the size of each amplified PCR product. Primers of insulin-1, GLUT-2, glucokinase, Pdx-1 and Nkx6.1 were previously described $[33,34]$. The housekeeping gene $\beta$-actin was used as a constitutive control for normalization [35]. The reaction mixture was carried out in a total volume $20 \mu \mathrm{L}$ consisted of $10 \mu \mathrm{L} 2 \mathrm{x}$ SensiFast SYBR, $3 \mu \mathrm{L}$ cDNA, $5.4 \mu \mathrm{l} \mathrm{H} 2 \mathrm{o}$ (distilled water), $0.8 \mu \mathrm{l}$ of each primer. The PCR cycling conditions were as follows: $95^{\circ} \mathrm{C}$ for $2 \mathrm{~min}$ followed by 40 cycles of $94^{\circ} \mathrm{C}$ for $15 \mathrm{~s}$, annealing temperatures $58^{\circ} \mathrm{C}$ for $30 \mathrm{~s}$, and $72^{\circ} \mathrm{C}$ for $20 \mathrm{~s}$. At the end of the amplification phase, a melting curve analysis was performed to confirm the specificity of the PCR product.

Table 1. Oligonucleotide primers sequence and the polymerase chain reaction (PCR) product size of the studied genes

\begin{tabular}{|c|c|c|c|}
\hline Gene & Oligonucleotide sequence & $\begin{array}{c}\text { Size } \\
(\mathrm{bp})\end{array}$ & Reference \\
\hline Insulin-1 & $\begin{array}{c}\text { f 5'-ATGGCCCTGTGGATGCGCTT-3 } \\
\text { r 5'-TAGTTGCAGTAGTTCTCCAGCT-3 }\end{array}$ & 331 & {$[33]$} \\
\hline GLUT-2 & $\begin{array}{c}\text { f 5'-TTAGCAACTGGGTCTGCAAT-3 } \\
\text { r 5'-TCTCTGAAGACGCCAGGAAT-3 }\end{array}$ & 243 & {$[33]$} \\
\hline Glucokinase & $\begin{array}{c}\text { f 5'CACCCAACTGCGAAATCACC-3' } \\
\text { r 5'-CATTTGTGGGGTGTGGAGTC-3' }\end{array}$ & 162 & {$[33]$} \\
\hline Pdx-1 & $\begin{array}{c}\text { f 5'-GGGACCGCTCAAGTTTGTAA-3' } \\
\text { r 5'-GGCTTAACCTAAACGCCACA-3' }\end{array}$ & 247 & {$[34]$} \\
\hline Nkx6.1 & $\begin{array}{c}\text { f 5'-GGGCTTGTTGTAATCGTCGT-3' } \\
\text { R5'-ACTTGGCAGGACCAGAGAGA-3' }\end{array}$ & 209 & {$[34]$} \\
\hline$\beta$-actin & $\begin{array}{c}\text { f5'-TCGTGCGTGACATTAAAGAG-3' } \\
\text { r5-ATTGCCGATAGTGATGACCT-3' }\end{array}$ & 260 & {$[35]$} \\
\hline
\end{tabular}

\subsection{Statistical Analysis}

Results obtained were expressed as mean \pm standard error (SE). All data obtained were statistically analyzed by software SPSS program package version 17 [36]. One-way analysis of variance (ANOVA) followed by Dennett's test was used to compare among three groups. $\mathrm{P}$ - Value was considered significant at the level of ( $\mathrm{P}$ $<0.05)$. Calculations of real time PCR results were performed by determining the values of $\Delta$ cycle threshold $(\Delta \mathrm{Ct})$ using $\beta$-actin) as a constitutive control for normalization. Then $2-\Delta \Delta \mathrm{Ct}$ for each treatment was calculated and statistical analysis for data was performed as previously described [37].

\section{Results}

\subsection{Influence of $L A$ Seed Extract on Serum Insulin of Diabetic Rats}

Quantitative measurement of serum insulin by ELIZA technique was assayed in all experimental groups to investigate the effect of LA aqueous extract for 60 days in improvement of pancreatic B-cells function and secretion of insulin. Diabetic rats noticed a significant reduction in insulin concentration when compared to control nondiabetic rats. While treatment of diabetic rats with $L A$ aqueous extract induced an increase in serum insulin when compared to the diabetic group Figure 1 (a).

\subsection{Influence of $L A$ Seed Extract on FBG and HbA1c of Diabetic Rats}

Fasting blood glucose measurement and glycosylated hemoglobin analysis were performed to evaluate the effectiveness of oral gavage of LA aqueous extract for 60 days on diabetes-induced hyperglycemia in diabetic rats. Figure 1. (b \& c) revealed that diabetic rats displayed a significant rise in $\mathrm{FBG}$ and $\mathrm{HbA} 1 \mathrm{c} \%$ as compared to control normal rats. Oral treatments of diabetic rats with $L A$ aqueous extract significantly reduced $(\mathrm{P}<0.05)$ FBG and $\mathrm{HbA} 1 \mathrm{c} \%$ as compared to the diabetic group. 


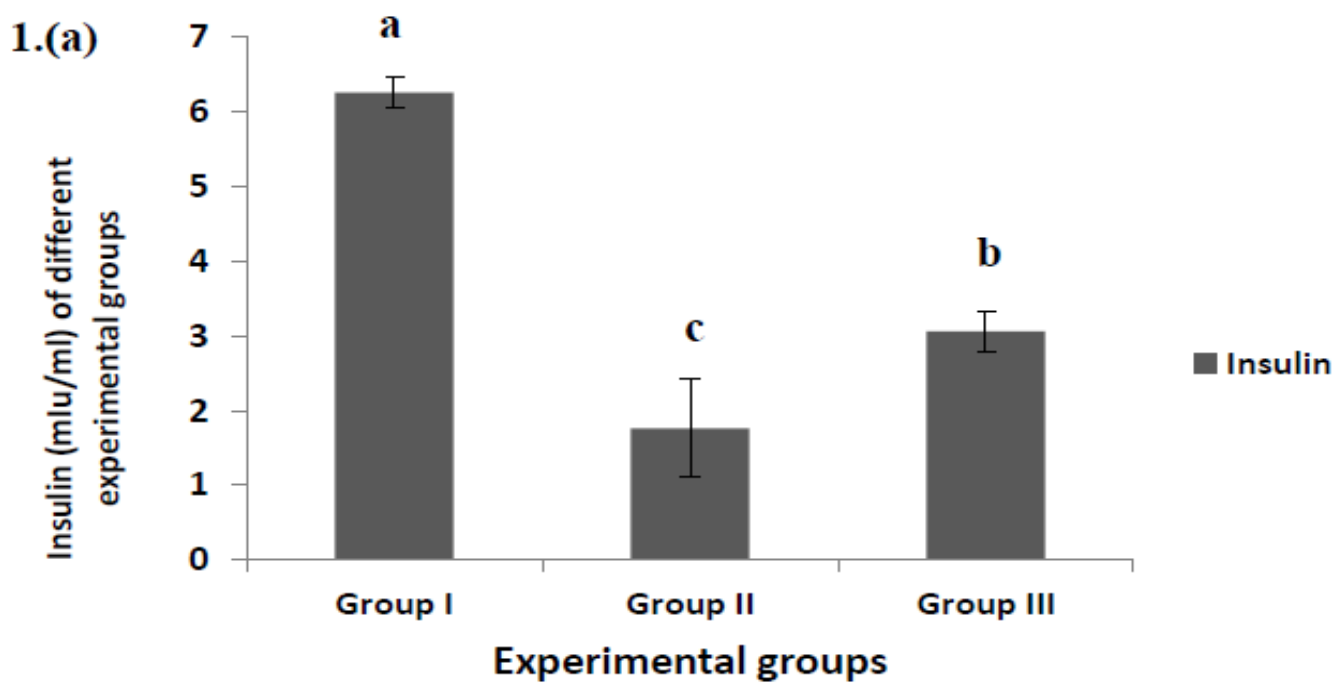

Figure 1. (a). Effect of LA aqueous extract $(7 \mathrm{mg} / 100 \mathrm{~g}$ B.wt) on insulin in STZ-diabetic rats. Number of rats in each group ( $\mathrm{n}=10)$. Values are mean \pm SE, SE: Standard error. Small alphabetic letters show significance when $(\mathrm{P}<0.05)$
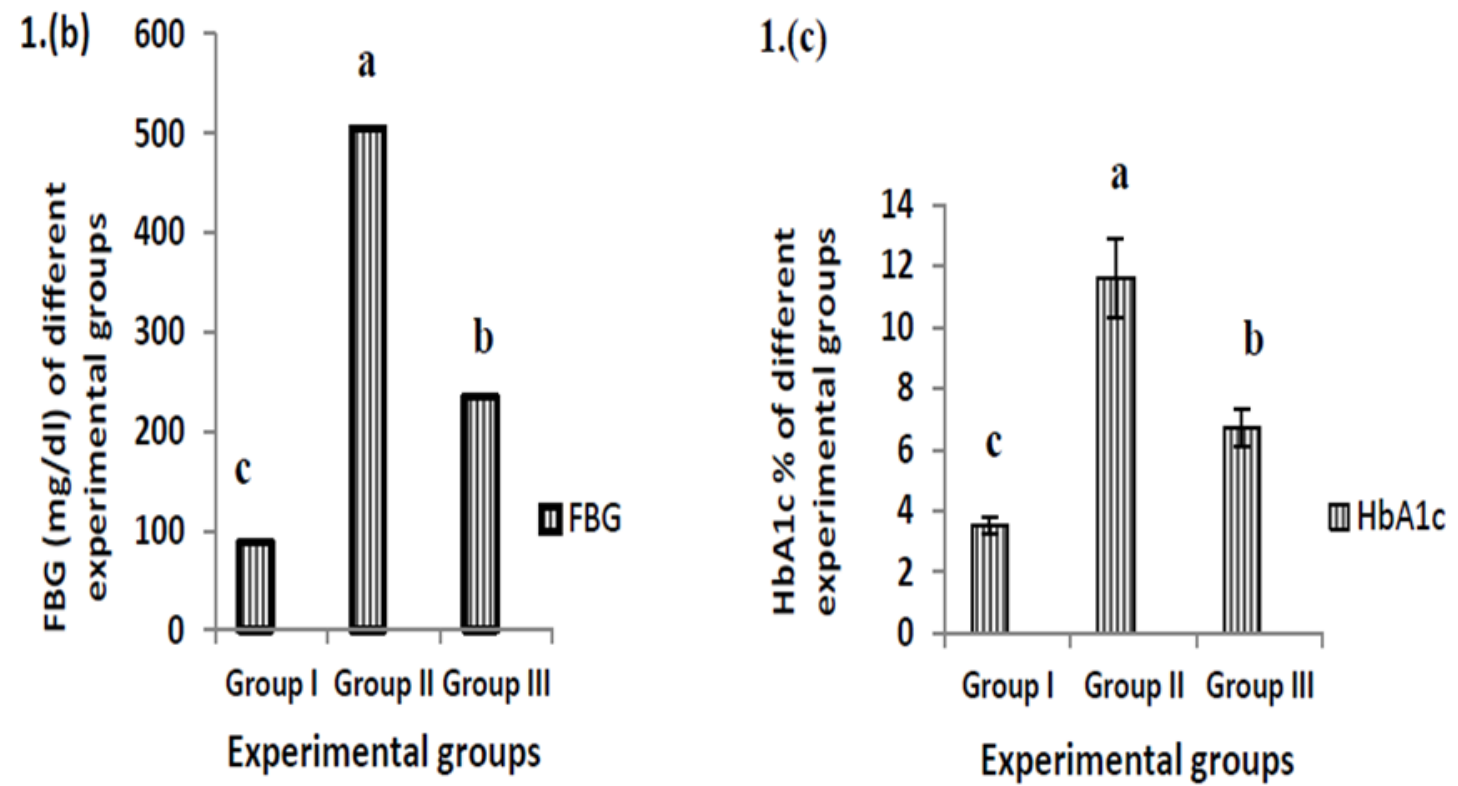

Figure 1. (b): Effect of LA aqueous extract (7mg/100g B.wt) on FBG in STZ-diabetic rats. (c): Effect of LA aqueous extract (7mg/100g B.wt) on HBA1c in STZ-diabetic rats. Number of rats in each group $(n=10)$. Values are mean \pm SE, SE: Standard error. Small alphabetic letters show significance when $(\mathrm{P}<0.05)$

\subsection{Influence of $L A$ Seed Extract on Serum Lipid Profile of Diabetic Rats}

Serum TC, TAG and HDL-C were analyzed using colorimetric methods, in addition to calculation of LDL-C and VLDL-C levels in order to investigate the effect of oral gavage of LA aqueous extract for 60 days on diabetes-induced hyperlipidemia in STZ-diabetic rats. Results showed in Figure 2 (a \& b) revealed that TC, TAG, LDL-C \& VLDL-C were increased in diabetic rats; while HDL-cholesterol was decreased when compared to normal rats. Following gavage of diabetic rats with LA aqueous extract for constitutive 60 days, they showed significant $(\mathrm{P}<0.05)$ reduction in TC, TAG, LDL-C and VLDL-C, while HDL-C showed a significant rise as compared to diabetic group.

\subsection{Influence of $L A$ Seed Extract on Pancreatic Expression of Pdx-1, Nkx6.1, Insulin-1, Liver GLUT-2 and Glucokinase of Diabetic Rats}

Real-time PCR analysis was performed to determine mRNA levels of pancreatic Pdx-1, Nkx6.1, insulin-1, liver GLUT-2 and glucokinase in normal, diabetic and diabetictreated rats with LA seed extract for 60 days. Dosing of STZ-diabetic rats by LA could affect the expression of biomarkers genes for $\beta$ cell function and insulin effectiveness. Results summarized in Figure 3. (a,b,c,d,e) showed that STZ significantly down regulate the expression of pancreatic and liver genes in diabetic rats in comparison to normal and diabetic-treated rats. Gavage of LA seed extract to STZ-diabetic rats induced slight increase in mRNA of the after mentions genes than in diabetic rats. 

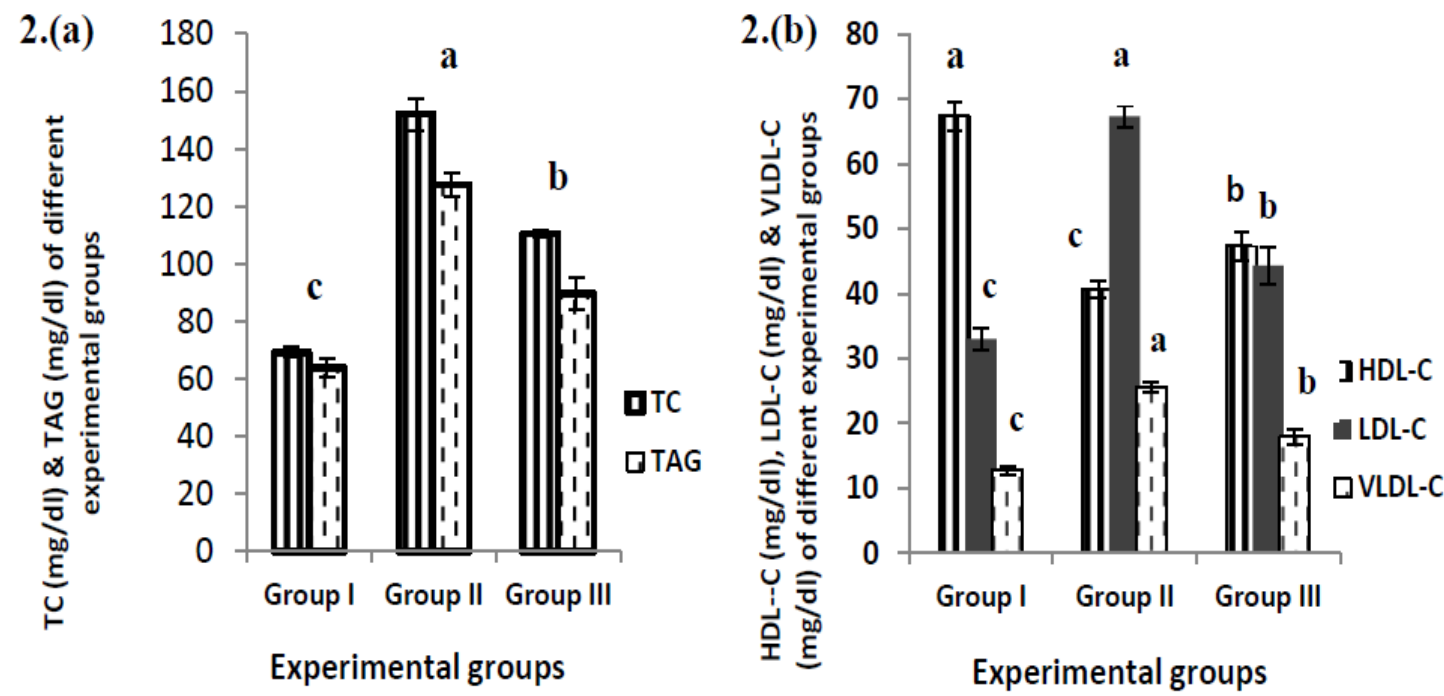

Figure 2. (a): Effects of LA aqueous extract (7mg/100g B.wt) on TC and TAG in STZ-diabetic rats; (b): Effects of LA aqueous extract (7mg/100g B.wt)) on HDL-C, LDL-C and VLDL-C in STZ-diabetic rats. Number of rats in each group $(n=10)$. Values are mean \pm SE, SE: Standard error. Small alphabetic letters show significance when $(\mathrm{P}<0.05)$
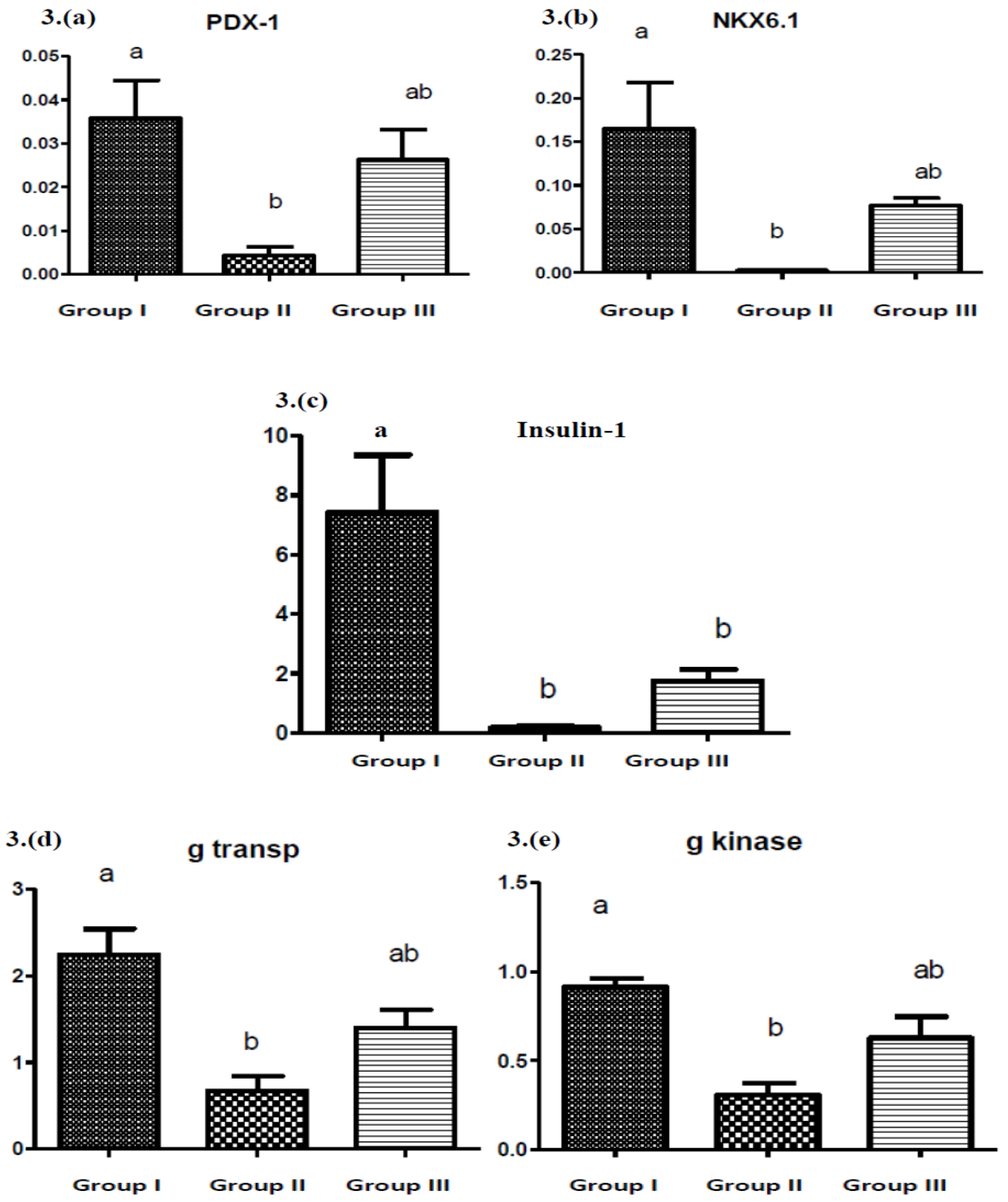

Figure 3. (a,b,c,d,e): m.RNA levels of pancreatic Pdx-1, Nkx6.1, insulin-1, liver, glucose transporter-2 and glucokinase in the control, STZ-diabetic and diabetic rats treated with LA aqueous extract $(7 \mathrm{mg} / 100 \mathrm{~g}$ B.wt) for 60 days. Number of rats in each group ( $\mathrm{n}=10)$. Values are mean $\pm \mathrm{SE}$, SE: Standard error. Small alphabetic letters show significance when $(\mathrm{P}<0.05)$ 


\section{Discussion}

DM is a chronic disease characterized by hyperglycemia and hyperlipidemia [38]. DM type 1 is an auto-immune disease, characterized by long term damage of B-cells and absolute deficiency in insulin secretion [39]. Liver has avital role in both glucose and lipid homeostasis because it is an insulin-dependent tissue, severely affected by DM [40]. Oral hypoglycemic agents showed high drug tolerance [41]. Some patients have insulin resistance and do not respond well to the conventional drugs but show a good response to natural products [42]. Different medicinal plants have been known for their anti-diabetic effects by a diversity of mechanisms by way of enhancing pancreatic $\beta$-cells regeneration, enhancing glucose dependent-insulin secretion in diabetic rats and improving insulin sensitivity [43]. A number of anti-diabetic herbs have been used for a long period for treatment of hyperglycemia and hyperlipidemia in different diabetic animal models $[44,45,46,47]$.

In this context, the diabetic rats exhibited hyperglycemia which indicated by increased blood glucose and glycosylated hemoglobin percent with reduction in serum insulin concentration when compared to control group. Similar results reported a significant reduction in insulin sensitivity in STZ-treated rodents and explained this by the hyperglycemic state which modulates insulin signaling at the insulin receptor (IR) level in liver and skeletal muscle [48]. Also, STZ leads to beta cell damage, impedes glucose oxidation and glucose stimulated insulin secretion in pancreatic b-cells through DNA methylation and fragmentation corresponding to its cytotoxic effect followed by a continuous drop in cellular NAD+ levels that induces cell death as well as kidney and liver toxicity $[10,12,49]$.

STZ also increased glucose binding to hemoglobin and producing glycosylated hemoglobin which increased up to $16 \%$ in DM, this metabolite is a good indicator of diabetes control $[50,51]$. The obtained results revealed that diabetic rats treated with LA extract showed a significant reduction in fasting blood glucose and glycosylated hemoglobin levels, while there was a significant rise in serum insulin concentration when compared to diabetic non-treated rats. This result in accordance with that reported by [51] who showed that repeated Lupinus albus dry extract in type 2 diabetic adult patients significantly diminished fasting and postprandial plasma glucose, fasting as well as HbAlc. It was shown that $L A$ supplementation in normal and alloxan-diabetic animals increased serum insulin as well as in diabetic and healthy Humans [52,53]. LA extract contains bioactive compounds like polyphenol, Saponins and lupanine alkaloids which induce anti-hyperglycemic effects via stimulation of insulin action on peripheral tissues, suppression of carbohydrate digestion and its absorption $[54,55]$. The main quinolizidine alkaloids (QAs) present in many Lupinus species Lupanine and Sparteine [56]. Quinolizinic alkaloids from Lupinus species induced insulin release from cultured pancreatic islets of normal rats, and established that Lupanine, the most abundant alkaloids in Lupinus that potentiates glucose-stimulated insulin release via increasing insulin gene expression [57].

There are major signaling pathways in the pancreatic $\beta$-cells through which, Lupinus alkaloids induce a direct stimulatory effect on insulin secretion [58]. The major intracellular signals in insulin secretion are $\mathrm{Ca}^{2+}$, ATP, cAMP and phospholipid-derived signals such as inositol 1, 4, 5-triphosphate (IP3) and diacylglycerol (DAG) [59]. The principal mechanism of insulin secretion is glucose-stimulated insulin secretion (GSIS). An increase in mitochondrial ATP concentration (or ATP/ADP ratio) due to increased glucose metabolism closes the ATP-sensitive $\mathrm{K}^{+}\left(\mathrm{K}_{\mathrm{ATP}}\right)$ channels, depolarizing the $\beta$-cell membrane and opening the voltage-dependent $\mathrm{Ca}^{2+}$ channels (VDCCs), which allows $\mathrm{Ca}^{2+}$ influx. The resultant rise in $\left[\mathrm{Ca}^{2+}\right]$ in the $\beta$-cell triggers exocytosis of insulin granules. Thus, $\mathrm{K}_{\text {ATP }}$ channels couple metabolic changes to membrane potential [60]. Treatment with Lupinus $\gamma$-conglutin had enhanced the state of insulin resistance as discovered by a reduction of HOMAS in treated diabetic animals [61]. Also, $\gamma$-Conglutin declines plasma glucose level in mice and healthy Humans [62]. It was approved that Lupinus $\gamma$-conglutin activates the IRS-1/PI-3-kinase pathway, which is vital in glucose homeostasis and protein synthesis and the translocation of GLUT-4 to the cell surface [63].

$\mathrm{DM}$ is a metabolic disease, altered lipid metabolism, leads to abnormal lipid profile in diabetic patients [64]. Insulin regulates different steps in lipid metabolism, promotes lipid synthesis and inhibits lipid degradation in adipose and liver tissues [65]. In diabetic rats, serum lipid profile was elevated 2-fold more when compared to control rats [66]. Our results obtained revealed that, diabetic rats showed hyperlipidemia with significant elevation of TC, TAG, LDL-C, VLDL-C and AI, as well as significantly decreased HDL-C. Lipid abnormalities usually associated with DM, leads to hypercholesterolemia and hypertriglyceridemia [67]. Defective insulin secretion in DM leads to defective lipoprotein lipase activation, thus inducing hypertriglyceridemia [68].

Treatment of diabetic rats with LA seed extract for successive 60 days induced a significant decline in TC, TAG, LDL-C and AI. Meanwhile, it exerted an elevation in HDL-C as compared with diabetic non-treated rats. This improvement in lipid profile of diabetic rats indicated that LA extract induced hypolipidemic and anti-atherosclerotic effects. Anti-hyperlipidemic effect of LA extract was previously reported in type- 2 diabetic patients, diabetic rats and rabbits $[69,70]$. The potential hypolipidemic effect of LA extract in diabetic-treated rats may be attributed to its soluble dietary fibers, which retard the absorption of fats [71]. Additionally, the two major elements albumin and globulin of LA proteins which represent a ratio of 1:9, induced an increment in low-density lipoprotein cholesterol receptors activity, enhanced LDL-uptake from plasma and their destruction [72]. Also, LA proteins inhibit 3-hydroxy-3-methyl-glutaryl-CoA reductase (HMG-CoA reductase) the enzyme responsible for cholesterol synthesis [73]. Lupin proteins had vital role in reduction of the expression of genes SREBP-1c and HMG-CoA reductase [74]. Moreover, Lupine seed encloses high quantities of proteins and non-starch polysaccharides that able to reduce intestinal absorption of lipids through its binding to bile acids and improve loss of these acids in the feces [75]. Upon Lupine therapy, a better glycemic control improved serum lipid profile in diabetic rats [76]. 
Concerning the gene expression pattern, diabetic rats treated with LA modulate the expression of some selected biomarkers genes for beta cell activity and insulin effectiveness. Results revealed that, LA supplementation exert a non- significant effect on the genes expression of glucokinase, glucose transporter, PDX-1 and NKX6.1; although it is mildly increased than that expressed in diabetic group but did not reach to control levels. In addition, STZ significantly downregulate the expression of insulin genes in diabetic group as previously reported in diabetic rats [77]. The potential anti-diabetic effects of LA seed extract on diabetic rat might be achieved by increased insulin production or increased tissues insulin sensitivity that could lead to tissue glucose storage and utilization. Moreover, results demonstrated that, LA could significantly increase insulin reduce and reduce fasting blood glucose levels as compared to diabetic group. Similarly, insulin gene expression significantly increased in LA treated group than diabetic one. The possible anti-hyperglycemic effect of LA seed extract might be manifested by increasing insulin synthesis, stimulating its release from the beta cells and increasing cell receptors sensitivity to insulin. This appears through the induction of expression of the insulin gene in pancreatic cells [78]. Additionally, STZ induces a selective destruction of pancreatic beta cells, but leaving many of the surviving beta cells, which can be regenerated [79]. LA seed extract enhanced beta cells regeneration, improved insulin gene expression secretion and so increased insulin in the blood. Insulin receptors are expressed in different insulin sensitive tissues which can progress glucose utilization [80]. Human studies stressing the potential of lupin raw material for improvement of glycemic control [81].

\section{Conclusion}

In summary the present study concluded that diabetes induced hyperglycemia, hyperlipidemia and decreased tissues insulin sensitivity. $L A$ aqueous extract increased insulin with significant reduction in $\mathrm{FBG}, \mathrm{HbA} 1 \mathrm{c} \%$ and significantly improved serum lipid profile in addition to a mild increase in expression of biomarkers genes for pancreatic $\beta$ eta cells ( $\beta$-cells) function, insulin gene, liver glucokinase and GLUT-2 in diabetic rats. Thus, results obtained from our study, suggested that $L A$ a nutraceutical could be recommended for its hypoglycemic, hypolipidemic effects and its potential effect in improving insulin secretion from beta cells.

\section{Ethics Approval and Consent to Participate}

All the animal procedures were performed in accordance with the Ethics Committee of the National Research Centre- Egypt with registration number (09/189). Authors are equally contributed in this work.

\section{Competing Interests}

The authors declare that they have no competing interests.

\section{Funding}

This research received no specific grant from any funding agency in the public, commercial, or not-for profit sectors.

\section{Acknowledgments}

The authors acknowledge the members of Biotechnology Lab, Faculty of Veterinary Medicine, Kafr Elsheikh University for their valuable advices and cooperation.

\section{List of bbreviations}

LA: Lupinus Albus; FBG: Fasting blood glucose; HbA1C: Glycosylated hemoglobin; TC: Total cholesterol; TAG: Triacylglycerol; LDL-C: Low density lipoprotein cholesterol; HDL-C: High density lipoprotein cholesterol; VLDL-C: Very low density lipoprotein cholesterol; Ins-1: insulin-1; Pdx-1: Pancreatic and duodenal homeobox-1; Nkx6.1: homeobox protein; GLUT-2: glucose transporter-2.

\section{Orcid}

Basma Hamed ID http://orcid.org/0000-0003-4073-5151.

\section{References}

[1] Nayak BS, Marshall JR, Isitor G, Adogwa A (2011) Hypoglycemic and hepatoprotective activity of fermented fruit juice of Morinda citrifolia (Noni) in diabetic rats. Evid Based Complement Alternat Med.

[2] Abo KA, Fred-Jaiyesimi AA, Jaiyesimi AE. (2008). Ethnobotanical studies of medicinal plants used in the management of 2 diabetes: an analysis of the ACCORD randomized trial 376:419-30.

[3] Kaneto H, Katakami N, Kawamori D, Miyatsuka T, Sakamoto K, Matsuoka TA, Matsuhisa M, Yamasaki Y (2007) Involvement of oxidative stress in the pathogenesis of diabetes. Antioxid Redox Signal 9:355-66.

[4] Patricia O, Marı M, Ana A, Rebeca F, Fernando D , Celestin G (2006) Insulin sensitivity in streptozotocin-induced diabetic rats treated with different doses of 17ß-oestradiol progesterone. Exp Physiol 92:241-49.

[5] Szabat M, Lynn FC, Hoffman BG, Kieffer TJ, Allan DW, Johnson JD (2012) Maintenance of â-Cell Maturity and Plasticity in the Adult Pancreas Developmental Biology Concepts in Adult Physiology. Diabetes 61:65-71.

[6] Hart AW, Baeza N, Apelqvist A, Edlund H. (2002). Attenuation of FGF signalling in mouse â-cells leads to diabetes. Nature 408: 4-8.

[7] Shaffer AE, Taylor HR, Benthuysen JR, Liu J, Thorel F, Yuan W (2013) Nkx6.1 controls a gene regulatory network required for establishing and maintaining pancreatic beta cell identity. PLoS Genet 9: 1-15.

[8] Shrilatha B , Muralidhara N. (2007). Early oxidative stress in testis and epididymal sperm in streptozotocin- induced diabetic mice: its progression and genotoxic consequences. Reprod Toxicol 23: 578-87.

[9] Hosokawa M, Dolci W, Thorens D. (2001). Differential sensitivity of GLUT1- and GLUT2-expressing beta cells to streptozotocin. Biochem Biophys Res Commun 289: 1114-17.

[10] Lenzen S (2008). The mechanisms of alloxan- and streptozotocininduced diabetes," Diabetologia 51: 216-26. 
[11] Dufrane D, Van Steenberghe M, Guiot Y, Goebbels RM, Saliez A, Gianello P. (2006). Streptozotocin-induced diabetes in large animals (pigs/primates): role of GLUT2 transporter and cell plasticity. Transplantation 81:36-45.

[12] Kramer J, Moeller EL, Hachey A, Mansfield KG, Wachtman LM. (2009). Differential expression of GLUT2 in pancreatic islets and kidneys of Newand Old World nonhuman primates Am J Physiol Regul Integr Comp Physiol 296:786-93.

[13] Laukkanen O, Lindstr"om J, Eriksson J. (2005). Polymorphisms in the SLC2A2 (GLUT2) gene is associated with the conversion from impaired glucose tolerance to type 2 diabetes: The Finnish Diabetes Prevention Study. Diabetes 54:2256-60.

[14] Ismail BF, Craven T, Banerji MA. (2010). Effect of intensive treatment of hyperglycemia on microvascular outcomes in type on microvascular outcomes in type 2 diabetes: an analysis of the ACCORD randomized trial. Lancet 7:419-30.

[15] Cho SY, Park JY, Park EM, Cho MS, Lee MK, Jeon SM, Kim MJ, Park YB. (2002). Alternation of hepatic antioxidant enzyme activities and lipid profile in streptozotocin-induced diabetic rats by supplementation of dandelion water extract. Clin Chim Acta. 317: 109-17.

[16] Awanish P, Poonam T, Rishabh P, Rashmi S, Shambaditya G. (2011). Alternative therapies useful in the management of diabetes: A systematic review. J Pharm Bioallied Sci 3: 504-12.

[17] Brand T, Brandt DA. (2002). Alkaloid content of South African lupins (L. luteus, L. albus and L angustifolius species) and determination thereof of by near infra-red reflectance spectroscopy. S Afr J Anim Sci 1: 11-12.

[18] Mansour HA, Newairy AA, Yousef MI, Sheweita SA. (2002). Biochemical study on the effects of some Egyptian herbs in alloxan- induced diabetic rats. Toxicol 170: 221-28.

[19] Oraby FS, Hussein Farrag R, Khalil MY, Hussein JS, Abou El-Soud NHA. (2008). Hypoglycemic effect of selected herbal extracts on streptozotocin induced diabetic rats. J Appl Sci Res 4(12): 2001-12.

[20] Pereira FC, Ouedraogo R, Lebrun P, Barbosa, RM, Cunha AP, Santos RM, Rosario LM. (2001). Insulinotropic action of white Lupine seeds (Lupinus albus L): effects on ion fluxes and insulin secretion from isolated pancreatic islets. Biomed Res 22(2): 23.

[21] Terruzzi I, Senesi P, Magni C, Montesano A, Scarafoni A, Luzi L, Duranti M. (2011). Insulin-mimetic action of conglutin- $\gamma$, a lupin seed protein, in mouse myoblasts. Nutr Metab Cardiovas 21: 197-205.

[22] Bertoglio JC, Calvo MA, Hancke JL, Burgos RA, Riva A, Morazzoni P, Ponzone C, Magni C, Duranti M (2011). Hypoglycemic effect of lupin seed $\gamma$-conglutin in experimental animals and healthy human subjects. Fitoterapia 82: 933-38.

[23] Basma HM, Walaa FA, Yousef YE, Nabil AH. (2015). Protective Role of Wheat Germ Oil against Hyperglycemia and Hyperlipidemia in Streptozotocin Induced Diabetic Rats. Asian Journal of Animal and Veterinary advances 10 (12): 852-864.

[24] Eman GEH, Samia MA, Tarek AA, Anwaar AM. (2013). Hypoglycemic Effect of the Aqueous Extracts of Lupinus albus, Medicagosativa (Seeds) and Their Mixture on Diabetic Rats. The Egyptian Journal of Hospital Medicine 25: 685-698.

[25] Mohamed TM, Mojtaba GJ, Mohamed HM, Mehdi RB, Mahvash J, Fatemeh S. (2013). Atorvastatin inhibits brain oxidative stress of streptozotocin-induced diabetic rat. Exp Appl Anim Sci 1: $35-43$.

[26] Szudelskit T. (2001). The mechanism of alloxan and streptozotozin action in B cells of the rat pancreas. Physiol Res 50: 537-46.

[27] Murthy H, Dandin V, Lee E, Paek K. (2014). Efficacy of ginseng adventitious root extract on hyperglycemia in streptozotocin-induced diabetic rats. J Ethnopharmacol. 153: 917-21.

[28] Anderson L, Dinesen B, Joresen PN, Poulsen F, Roder MF. (1993). Enzyme immune assay for intact human insulin in serum or plasma. Clin Chim Acta 38: 578-85.

[29] Hanas R, John G. (2010). Consensus statement on the worldwide standardization of the hemoglobin A1c measurement. Clin Chem Lab Med 48:775-76.

[30] Ellefson RE and Caraway WT. (1976). Lipids and lipoproteins, "in fundamentals of clinical chemistry. Edited by Norbert and Tietz Philadelphia, Saunders.

[31] Bucolo G, David H. (1973). Quantitative determination of serum triglycerides by the use of enzymes. Clin Chem 19: 476-82.
[32] Friedewald WT, Levy RI, Fredrickson DS. (1972). Estimation of the concentration of low-density lipoprotein cholesterol in plasma, without use of the preparative ultracentrifuge 18(6): 499-50.

[33] Alkaladi A, Abdelazem A, Afifi M. (2014). Antidiabetic activity of zinc oxide and silver nanoparticles on streptozotocin-induced diabetic rats. Int J Mol Sci 15: 2015-23.

[34] Claudia S, Jesús J, Julia P, Imelda G, Ana E, Esther U, Salud P, Luis R. (2014). Insulin gene expression and its detection in the rat kidney. IJLRST 3(3):221- 27.

[35] Pfaffl MW. (2001). A new mathematical model for relative quantification in real time RT-PCR. Nuc Acids Res 29: 2002-7.

[36] SPSS PC (2004) SPSS for windows release 17 SPSS. Inc. USA

[37] Livak KJ, Schmittgen TD. (2001). Analysis of relative gene expression data using real-time quantitative PCR and the 2(-Delta Delta C(T)) Method. Methods 25:402-8.

[38] Rader DJ, Alexander ET, Weibel GL, Billheimer J, Rothblat GH. (2009). The role of reverse cholesterol transport in animals and humans and relationship to atherosclerosis. Lipid Res 50: 189-94.

[39] Delmastro MM, Piganelli JD (2011) Oxidative stress and redox modulation potential in type 1 diabetes. Clin. Dev. Immunol.

[40] Lyra R, Oliveira M, Lins D, Cavalcanti N. (2006). Prevention of type 2 diabetes mellitus. Arq Bras Endocrinol Metabo 50: 239-49.

[41] Srivastava N, Tiwari G, Tiwari R, Bhati LK, Awani K. (2013) Neutraceutical approaches to control diabetes. Natural Sci Biol Med 3 (2): 168-76.

[42] Waqar MA, Aijaz S, Shaukat S, Waqar A. (2009). Herbs can effectively talk with diabetogenes. Chem Soc Pakistan 31:677-87.

[43] Daisy P, Jasmine R, Ignacimuthu S. (2009). A novel Steroid1 from Elephantopus scaber L. an Ethnomedicinal plant with antidiabetic activity. Phytomed 16: 252-57.

[44] Aguilar-Santamaria L, Ramirez G, Nicosio P, Alegria-Reyes CA, Herrera-Arellano D. (2009). Antidiabetic activities of Tecomastans (L.) Juss. Ex Kunth. J Ethnopharmacol 10: 1010-16.

[45] Gupta S, Sharma SB, Bansal SK, Prabhu KM. (2009). Antihyperglycemic and hypolipidemic activity of aqueous extract of Cassia auriculata L. leaves in experimental diabetes. Ethnopharmacol 123:499-503.

[46] Zhou JY, Zhou SW, Zeng SY, Zhou JY, Jiang MJ, He Y. (2012). Hypoglycemic and hypolipidemic effects of ethanolic extract of Mirabilis jalapa L. root on normal and diabetic mice. Evid Based Complement Alternat Med 257374.

[47] Patel J, Kumar S, Patel H, Prasad AK, Iyer SV, Vaidya SK. (2012). Hypoglycaemic and hypolipidaemic potential of aerial parts of Amaranthus viridis (L.) Merr. in streptozotocin induced diabetic rats. Int J Pharm Arch 1: 1-6.

[48] Ordonez P, Moreno M, Alonso A, Fernandez R, Diaz F, Gonzalez C. (2007). Insulin sensitivity in STZ-induced diabetic rats treated with different doses of 17 beta-oestradiol or progesterone. Exp Physiol 92(1):241-49.

[49] Lenzen S. (2008). "The mechanisms of alloxan- and Streptozotocin-induced diabetes, Diabetologia 51(2): 216-26.

[50] Kumar V, Ahmed D, Anwar F, Ali M, Mujeeb M (2013) Enhanced glycemic control, pancreas protective, antioxidant and hepatoprotective effects by umbelliferon- $\alpha$ - D- glucopyranosyl(2I- 1II)- $\alpha$ - D-glucopyranoside in streptozotocin induced diabetic rats. Springer plus 2: 639 .

[51] Kumar V, Verma A, Ahmed D, Sachan NK, Anwar F, Mujeeb M. (2013). Fostered antiarthritic upshot of moringa oleifera lam. Stem bark extract in diversely induced arthritis in wistar rats with plausible mechanism. Int J Pharm Sci Res 4: 3894-901.

[52] Mansour HA, Newairy AS, Yousef M, Sheweita SA. (2002). Biochemical study on the effects of some Egyptian herbs in alloxan induced diabetic rats. Toxicol 107221-228.

[53] Bertoglio JC, Calvo MA, Hancke A, Burgos RA, Riva A, Morazzoni, P. (2011). Hypoglycemic effect of lupin seed $\gamma$ conglutin in experimental animals and healthy human subjects. Fitoterapia 82: 933-938.

[54] Rim B, Mohamed KF, Mongia B, Mouna A, Moncef F, Naziha K, Aly R, Hedia S. (2016). Effect of Lupinus albus on Glycaemic Control, Plasma Insulin Levels, Lipid Profile and Liver Enzymes in Type 2 Diabetics. J of Food and Nut Res 4(9): 615-620.

[55] Lampart-Szczapa E, Siges A, Trojanowska K, Nogalakaluckam MM, Pacholek B. (2003). Chemical composition and antibacterial activities of lupin seed extracts on streptozotocin induced diabetic rats. J Appl Sci Res 4:2001-12. 
[56] Hannan JMA, Rokeya B, Faruque O. (2007). Effect of soluble dietary fiber fraction of Trigonella foenum graecumon glycemic, insulinemic, lipidemic and platelet aggregation status of type 2 diabetes mellitus in South Western Nigeria. J Ethnopharmacol 115: 67-71.

[57] Wink M, Meissner C and Witte L. (1995). Patterns of quinolizidine alkaloids in 56 species of the genus Lupinus. Phytochemistry 38:139-153.

[58] Mats W, Carmen M, Gurrola-Díaz, Belinda VG, Michael W, Pedro M, García L, Martina D. (2015). Lupanine Improves Glucose Homeostasis by Influencing KATP Channels and Insulin Gene Expression. Molecules 20:19085-19100.

[59] Prentki M, Matschinsky FM. (1987). $\mathrm{Ca}^{2+}$, cAMP, and phospholipid-derived messengers in coupling mechanisms of insulin secretion. Physiol Rev 67:1185-1248.

[60] Ashcroft FM (1988) Adenosine 5'-triphosphate-sensitive potassium channels. Annu. Rev. Neurosci 11:97-118.

[61] García-López PM, Garzón de la Mora P, Wysocka W, Maiztegui B, Alzugaray ME, del Zotto H, Borelli MI. (2004). Quinolizidine alkaloids isolated from lupinus species enhance insulin secretion. Eur J Pharmacol 504:139-142.

[62] Mansour HA, Newairy AS, Yousef M, Sheweita SA. (2002). Biochemical study on the effects of some Egyptian herbs in alloxan induced diabetic rats. Toxicol 107:221-228.

[63] Bertoglio JC, Calvo MA, Hancke A, Burgos RA, Riva A, Morazzoni, P. (2011). Hypoglycemic effect of lupin seed $\gamma$-conglutin in experimental animals and healthy human subjects. Fitoterapia 82: 933-938.

[64] Lovati MR, Manzoni C, Castiglioni S, Parolari A, Magni C, Duranti M. (2014). Lupin seed $\gamma$ conglutin lowers blood glucose in hyperglycaemic rats and increases glucose consumption of HepG2 cells. Br J Nutr 107:67-73.

[65] Terruzzi I, Senesi P, Magni C, Montesano A, Scarafoni A, Luzi L. (2011). Insulin-mimetic action of conglutin- $\gamma$, a lupin seed protein, in mouse myoblasts. Nutr Metab Cardiovasc Dis 21:197-205.

[66] Neelakantan N, Narayanan M, De Souza RJ and Van Dam RM. (2014). Effect of fenugreek (Trigonella foenumgraecum L) intake on glycemia: a meta-analysis of clinical trials. Nutr J 13:1-11.

[67] Pushpraj PN, Low HK, Mantikandan J and Tanbkh CH. (2007). Anti-diabetic effects of Cichorium intybas in streptozotocininduced diabetic rats. Ethnopharmacol 111:430-34.

[68] Ferre P and Foufelle F. (2007). SREBP-1c transcription factor and lipid homeostasis: clinical perspective. Horm Res 68 (2): 72-82.

[69] Veerapur VP, Prabhakar KR, Parihar VK, Bansal P, Srinivasan KK, Priyadarsini KI, Unnikrishnan MK. (2010). Anti-diabetic, hypolipidemic and antioxidant activity of Dodonaea viscosa aerial parts in streptozotocin- induced diabetic rats. Int J Phyto med 2: $59-70$.

[70] Shepherd J. (2005). Does statin monotherapy address the multiple lipid abnormalities in type-2 diabetes. Atheroscler 6:15-9.

[71] Shirwaikar A, Rajendran K, PunithaI SR. (2005). Antidiabetic activity of alcoholic stem extract of Coscinium fenestratum in streptozotocin nicotinamide induced type-2 diabetic rats. Ethnopharmacol 97:369-74.

[72] Wiedemann M, Gurrola-Díaz CM, Vargas-Guerrero B, Wink M, García-López PM, Düfer M. (2015). Lupanine Improves Glucose Homeostasis by Influencing KATP Channels and Insulin Gene Expression. Molecules 20:19085-19100.

[73] Baldeón M, Castro J, Villacrés E, Narváez L, Fornasini M. (2012). Hypoglycemic effect of cooked lupinus mutabilis and its purified alkaloids in subjects with type-2 diabetes. Nutr Hosp 27: 1261-1266.

[74] Australia New Zealand Food Authority. (2011). Lupin Alkaloids in Food: A Toxicological Review and Risk Assessment; Australia New Zealand Food Authority: Canberra, Australia; Wellington, New Zealand.

[75] Naruszewicz M, Nowicka G, Klosiewicz-Latoszek L, Arnoldi A and Sirtori C. (2006). Effect of lupin protein (Lupinus albus) on cardiovascular risk factors in smokers with mild hypercholesterolemia. Circulation 114(18): 874.

[76] Marchesi M, Parolini C, Diani E, Rigamonti E, Cornelli L, Arnoldi A, Sirtori CR, Chiesa G. (2008). Hypolipidaemic and antiatherosclerotic effects of lupin proteins in a rabbit model. $\mathrm{Br} \mathrm{J}$ Nutr 100: 707-10.

[77] Redondo S, Martínez-González J, Urraca C, Tejerina T. (2011). Emerging therapeutic strategies to enhance HDL function. Lipids Health Dis 10: 175.

[78] Sirtori CR, Lovati MR, Manzoni C, Castiglioni S, Duranti M, Magni C, Morandi S, D'Agostina A, Arnoldi A. (2004). Proteins of white lupin seed, a naturally isoflavone-poor legume, reduce cholesterolemia in rats and increase LDL receptor activity in HepG2 cells. Nutr 134: 18-23.

[79] Yoshie-Stark Y, Wäsche A (2004) In vitro binding of bile acids by lupin protein isolates and their hydrolysates. Food Chemistry 88 : 179-184.

[80] Vargas-Guerrero B, García-López PM, González-Santiago AE, Domínguez-Rosales JA, Gurrola-Díaz CM. (2013). Reduction of Ins-1 gene expression and tissue insulin levels in n5-STZ rats. Biol Res 46(3): 281-288.

[81] Haytham A, Ali Omar A, Almaghrabi O, Mohamed E. (2014). Molecular mechanisms of anti-hyperglycemic effects of Costus speciosus extract in streptozotocin-induced diabetic Rats. Saudi Med J 35(12): 1501 